\section{ELIMINATIVNÍ \\ MATERIALISMUS, LIDOVÁ PSYCHOLOGIE A JAZYK MYŠLENÍ}

Abstrakt: Článek se věnuje rozboru eliminativního materialismu Paula a Patricie Churchlandových. $V$ jejich eliminativismu rozliším dvě argumentační linie: jednu usilující o eliminaci lidové psychologie a druhou kritizujicí hypotézu jazyka myšlení Jerryho Fodora. Následně se bliže zaměř́m na tuto druhou linii a ukáži, že predstavuje hlavní motiv práce Churchlandových od konce 80. let 20. století, a dále předvedu, proč úspěch argumentace proti hypotéze jazyka myšlení nezakládá dưvod $k$ eliminaci lidové psychologie. $V$ závěru text přezkoumám dưsledky tohoto prístupu pro roli lidové psychologie ve zkoumání mysli a ukazuje, že tato oslabená eliminativistická pozice stále naplňuje pưvodní zámér programu Churchlandových.

Klíčová slova: eliminativní materialismus; lidová psychologie; jazyk myšlení; konekcionismus

\section{MATĚJ DRAŽIL}

Katedra filozofie, Filozofická fakulta Univerzita Palackého v Olomouci Kř́ǐzovského 12, 77900 Olomouc email / matej.drazil01@upol.cz

(iD $0000-0002-7113-2217$

\section{Eliminative Materialism, Folk Psychology and the Language of Thought}

Abstract: The article provides an analysis of Paul and Patricia Churchland's eliminative materialism. I will distinguish two lines of argument in their eliminativism: one seeking to eliminate folk psychology and the second criticising Jerry Fodor's language of thought hypothesis. Then I will closely examine the second line of argument, and show that it represents the main motive of Churchland's work since the end of 1980 s and demonstrate why the success of the argument against the language of thought hypothesis does not constitute a reason for the elimination of folk psychology. Finally, I will examine the consequences of this approach for the role of folk psychology in the study of mind and show that the weakened eliminativist position still fulfils the original aim of Churchland's program.

Keywords: eliminative materialism; folk psychology; language of thought; connectionism

Příspěvek vznikl za podpory MŠMT ČR udělené UP v Olomouci (IGA_FF_2019_018).

(C) (P) Toto dílo podléhá licenci Creative Commons Attribution 4.0 International. 
Moderní eliminativní materialismus Paula a Patricie Churchlandových lze shrnout jako tvrzení, že lidová psychologie představuje radikálně chybnou a stagnující teorii, která bude eventuálně nahrazena silnější teorií kompletní neurovědy. ${ }^{1}$ Lidovou psychologií je myšlen způsob, jakým běžně vysvětlujeme a předvídáme jednání druhých (i nás samých) za pomoci propozičních postojů, jakými jsou například přesvědčení, přání, záměr a další. Když tedy běžně interpretujeme jednání ostatních lidí, děláme tak za pomoci lidově psychologické teorie a jí postulovaných entit - propozičních postojů. ${ }^{2}$ Tato teorie ovšem podle eliminativismu neobstojí ve srovnání s explanačně silnějšími teoriemi vycházejícími z neurobiologického zkoumání kognice a bude jimi nahrazena. Lidovou psychologii i její ontologii tak potká stejný osud, jaký potkal teorie vysvětlující pohyb těles za pomoci impetu, hoření za pomoci flogistonů či duševních nemocí za pomoci démonických posednutí.

Eliminativistické tvrzení o neadekvátnosti lidové psychologie je zpravidla dokládáno řadou pozorování. Za prvé eliminativisté poukazují na historii ostatních lidových teorií vysvětlující fyzikální a nebeské jevy, které byly postupně vyvráceny a nahrazeny systematickým vědeckým zkoumáním. ${ }^{3}$ Za druhé jsou zdůrazňovány konkrétní nedostatky lidové psychologie ve vysvětlení jevů, jako jsou rozdíly v inteligenci, funkce a dělení paměti, abnor-

1 Paul M. Churchland, „Eliminative Materialism and the Propositional Attitudes,“ The Journal of Philosophy 78, no. 2 (1981): 67-90; Patricia S. Churchland, Neurophilosophy: Toward a Unified Science of the Mind-Brain (Cambridge, MA: A Bradford Book, 1989). Článek se téměř výlučně zabývá eliminativním materialismem Paula a Patricie Churchlandových. Pod pojmem eliminativního materialismu či eliminativistů je tedy v textu myšlen právě přístup Churchlandových. $Z$ důvodu tohoto úzkého zaměření se text rovněž nebude zabývat širším kontextem a propojením lidové psychologie s otázkou individualismu a antiindividualismu, kterou se zabýval Tomáš Hř́bek či vztahem lidové psychologie a otázky vědomí řešeným v knize Tomáše Marvana a Michala Poláka. Viz Tomáš Hř́bek, Metafyzika antiindividualismu (Praha: Filosofia, 2008); Tomáš Marvan a Michal Polák, Vědomí a jeho teorie (Praha: Vyšehrad, 2015).

2 Otázka teoretické povahy lidové psychologie je problematickým a dosud otevřeným tématem, kterým se kvůli rozsahu práce nemohu blíže zabývat. Domnívám se ovšem, že čistě simulační prŕístupy $\mathrm{k}$ lidové psychologii se nedokázaly vypořádat s problémem kolapsu do určité formy teorie a stejný problém hrozí rovněž hybridním přístupům. Proto budu nadále pracovat s východisky teorie teorie. Pro detailnější diskusi viz William Ramsey, „How Not to Build a Hybrid: Simulation vs. Fact-Finding, "Philosophical Psychology 23, no. 6 (2010): 775-95; Luca Barlassina and Robert M. Gordon, „Folk Psychology as Mental Simulation,“ in Stanford Encyclopedia of Philosophy, accessed October 20, 2019, https://plato.stanford.edu/ entries/folkpsych-simulation/.

${ }^{3}$ Churchland, ,Eliminative Materialism.“ 
mální psychologie mentálně nemocných a řada dalších. ${ }^{4} \mathrm{Za}$ třetí je uváděna problematičnost začlenění intencionálních vysvětlení lidové psychologie do rostoucí syntézy fyzických, chemických, biologických a neurálních teorií. ${ }^{5}$ Tento zjevný nedostatek koherence s ostatními vědeckými teoriemi chápe eliminativní materialismus nikoli jako důkaz její unikátnosti, nýbrž jako poukaz $\mathrm{k}$ její potenciální defektnosti. Tato pozorování samožrejmě nepředstavují rezolutní argument pro eliminaci lidové psychologie, to ovšem ani nemají za cíl. Jedná se spíše o induktivní argumenty poukazující na možnost, že lidová psychologie je revidovatelnou a eliminovatelnou teorií, která v budoucnu bude nutně revidována, či dokonce eliminována.

Za silnější a jak se pokusím ukázat významnější argument eliminativního materialismu lze považovat kritiku jazykové povahy lidové psychologie. Churchlandová kritizuje lidovou psychologii rovněž za to, že zastává tzv.

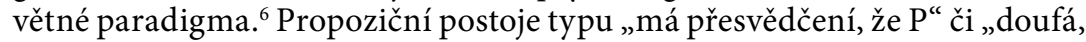

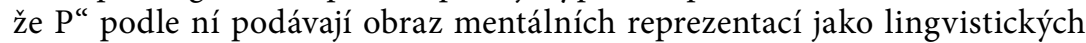
entit (de facto vět) a myšlení jako formálních jazykových operací na těchto entitách. Jak se eliminativní materialismus snaží ukázat, řada problémů spojených s tímto paradigmatem a vzestup alternativních konekcionistických pojetí kognice ovšem dávají tušit, že naše neurální architektura nerealizuje syntaktickou strukturu propozičních postojů a naše myšlení nemá jazykovou povahu.

$\mathrm{Z}$ těchto důvodů považuje eliminativní materialismus lidovou psychologii za radikálně chybnou teorii, která nepředstavuje vhodný nástroj pro chápání mysli. Ač lze v úvodním Churchlandovu článku z roku 1981 nalézt návrhy pro odstranění lidové psychologie dokonce i z každodenních mezilidských interakcí, ${ }^{7}$ domnívám se, že by tato radikální pozice neměla být vnímána jako reprezentativní eliminativismus Paula a Patricie Churchlandových. $Z$ většiny pozdějších textů lze vypozorovat, že jejich hlavním cílem je především umenšit vliv lidové psychologie na seriózní vědecké a filosofické zkoumání mysli. Především pak jde o to vyvázat toto bádání z nutnosti

\footnotetext{
${ }^{4}$ Ibid.; Churchland, Neurophilosophy, 369-73; Paul M. Churchland, Matter and Consciousness (Cambridge, MA: MIT Press, 2013), 143-45.

${ }^{5}$ Churchland, „Eliminative Materialism“; Churchland, Neurophilosophy.

${ }^{6}$ Churchland, Neurophilosophy, 386-88.

$7 \mathrm{~V}$ posledním oddílu článku uvádí Churchland fantastické př́pady nahrazení lidové psychologie novým ideálním jazykem či určitou formou telepatie. Tyto př́ílady lze považovat spíše za myšlenkové experimenty a ilustrace toho, jak by mohlo upuštění od lidové psychologie vypadat, spíše než seriózní predikce či plány. Churchland, „Eliminative Materialism,“ 84-90.
} 
sledovat kategorie a explananda lidové psychologie, která se mohou ukázat jako chybná a zcestná. ${ }^{8}$

Vedle kritiky lidové psychologie lze ovšem v eliminativismu Churchlandových sledovat ještě jinou významnou, často upozaděnou argumentační linii. Tou je již zmiňovaná snaha zpochybnit roli propozičních postojů jako prototypu mentálních reprezentací, a obecně pak kritika názoru, že mentální reprezentace mají lingvistickou strukturu a že se myšlení odehrává v mentálním jazyce. ${ }^{9}$ Tento názor, známý též jako hypotéza jazyka myšlení, byl představen Jerry Fodorem ve stejnojmenné knize $\mathrm{z}$ roku $1975^{10}$ a stal se jedním z ústř̌edních terčů kritiky Paula a Patricie Churchlandových. ${ }^{11}$

Rozdělení kritiky lidové psychologie a kritiky hypotézy jazyka myšlení pak zhruba odpovídá dělení na intencionální eliminativismus (intentional eliminativism) a sentenciální eliminativismus (sentential eliminativism), které zavedl Andy Clark ve svém článku z roku 1993.12 Intencionální eliminativismus podle Clarka odmítá nejen propoziční postoje k popisu mentálních stavů, ale také jakékoli popisy, které by se odvolávaly na propoziční obsah. ${ }^{13}$ Tuto pozici lze ztotožnit s odmítnutím lidové psychologie a snahou

8 Viz Patricia S. Churchland, "A Perspective on Mind-Brain Research," The Journal of Philosophy 77, no. 4 (1980): 185-207; Churchland, Neurophilosophy; Patricia S. Churchland, "Can Neurobiology Teach Us Anything about Consciousness?" Proceedings and Addresses of the American Philosophical Association 67, no. 4 (1994): 23-40.

${ }^{9}$ Pro tvrzení, že myslíme v médiu jazyka, budu rovněž používat označení sentencialismus. Viz Edouard Machery, „You Don't Know How You Think: Introspection and Language of Thought,“" The British Journal for the Philosophy of Science 56, no. 3 (2005): 469-85.

${ }^{10}$ Jerry A. Fodor, The Language of Thought (New York: T.Y. Crowell, 1975).

${ }^{11}$ Viz napr. Patricia S. Churchland, „Language, Thought, and Information Processing, “Noûs 14, no. 2 (1980): 147-70; Churchland, „Eliminative Materialism“; Churchland, Neurophilosophy; Paul M. Churchland, Plato's Camera How the Physical Brain Captures a Landscape of Abstract Universals (Cambridge: MIT Press, 2012). Tímto krokem a argumentací proti jazyku myšlení se churchlandovský eliminativismus částečně vyhýbá námitce $\mathrm{z}$ nepodloženého předvídání budoucnosti vědeckého výzkumu a filosofického prognosticismu, jak v textu z roku 1995 napsal Tomáš Hř́bek. Viz Tomáš Hř́bek, „Na obranu lidové psychologie,“ Filosofický časopis 43, č. 5 (1995): 858-61.

${ }^{12}$ Andy Clark, „The Varieties of Eliminativism: Sentential, Intentional and Catastrophic,“ Mind \& Language 8, no. 2 (1993): 223-33. Překlad „sentenciální“ volím na místo češtině bližšího „větný“ kvůli jeho blízkosti s termínem sentencialismus, se kterým je sentenciální eliminativismus ve sporu.

${ }^{13}$ Jako zástupce současného intencionálního eliminativismu by bylo možné uvést Alexe Rosenberga, který ve své nedávné knize argumentuje pro chybnost lidové psychologie na základě současné neurovědy, podle které se v mozku nenacházejí obsahy a intencionalita, jež lidová psychologie prredpokládá. Viz Alexander Rosenberg, How History Gets Things Wrong: The Neuroscience of Our Addiction to Stories (Cambridge, MA: MIT Press, 2018). 
o její eliminaci. Na druhou stranu sentenciální eliminativismus představuje mírnější stanovisko, které odmítá pouze to, že by naše vnitřní mentální stavy měly stejný lingvistický charakter jako propoziční postoje sloužící $\mathrm{k}$ jejich popisu. Hlavním terčem takového eliminativismu je pak především Fodorova hypotéza jazyka myšlení. V témže článku Clark píše, že argumenty předkládané Paulem a Patricií Churchlandovými od konce osmdesátých let dále, které vycházejí z nově nastupujícího konekcionismu, podporují spíše slabší pozici sentenciálního eliminativismu a nikoli už intencionálního.

Hlavním tématem tohoto textu bude právě sentenciální eliminativismus, který spolu s Clarkem hodnotím jako udržitelnější a perspektivnější pozici $\mathrm{v}$ rámci eliminativního materialismu. Za tímto účelem tedy nejprve stručně představím hypotézu jazyka myšlení Jerryho Fodora, která představuje hlavní cíl kritiky sentenciálního eliminativismu. V následujících částech se již budu věnovat argumentům, které eliminativismus předkládá proti Fodorově pozici. Nejprve se zaměřím na některé problémy spojené s hypotézou jazyka myšlení a následně se již budu věnovat konekcionistickému pojetí kognice jako alternativě a přímé konkurenci sentencialismu. Na závěr se pokusím zhodnotit, nakolik by vyvrácení hypotézy jazyka myšlení představovalo skutečný problém pro lidovou psychologii a její možné aplikace. Již zde může být předestřeno, že ač se $s$ Churchlandovými rozcházím v otázce povahy lidové psychologie, sdílím jejich stanovisko, že by lidová psychologie neměla zastávat výsadní pozici ve filosofickém a vědeckém zkoumání mysli.

\section{Jazyk a myšlení}

Eliminativní materialismus, či jeho sentenciální obdoba, je tedy primárně zaměřen proti jazykovému pojetí myšlení, vyjádřenému v hypotéze jazyka myšlení. Podle tohoto prŕstupu je myšlení analogické jazyku a probíhá na základě soukromého mentálního jazyka, nazývaného rovněž „mentálština" (mentalese).

Tento mentální jazyk se skládá ze systému reprezentací, které jsou realizovány v mozku organismu a mají kombinační syntax (combinatorial syntax) a skladebnou sémantiku (compositional semantics). ${ }^{14}$ Kombinační syntaxí je míněno, že složité molekulární reprezentace jazyka myšlení se skládají z jed-

\footnotetext{
${ }^{14}$ Viz Fodor, Language of Thought; Jerry A. Fodor and Zenon W. Pylyshyn, „Connectionism and Cognitive Architecture," Cognition 28, no. 1-2 (1988): 3-71; Susan Schneider, „The Language of Thought, " in Routledge Companion to Philosophy of Psychology, eds. John Symons and Paco Calvo (New York: Routledge, 2009).
} 
noduchých atomických symbolů a gramatických pravidel jazyka myšlení. Díky kombinační syntaxi je pak možné, že z konečného množství elementárních reprezentací lze generovat potenciálně nekonečné množství složitějších reprezentací. Tato vlastnost je označována jako produktivita jazyka. Tyto komplexní reprezentace pak mají skladebnou sémantiku, což znamená, že jejich sémantické vlastnosti jsou funkcí sémantických vlastností jejich atomických částí spolu se způsobem jejich kombinace (gramatikou). Jednotlivé atomické části (nebo též slova) jazyka myšlení se tedy skládají do složitějších „vět“, které lze ztotožnit s myšlenkami. Proto je tento př́ístup občas zjednodušován jako tvrzení, že mít myšlenku je obdobné tomu mít v hlavě uloženou větu. Následkem své skladebné struktury, vykazuje mentální jazyk systematicitu. Schopnost zastávat určitou myšlenku (např. „Marek miluje Janu") je nutně spojená se schopností porozumět jiné myšlence, která je první blízká (např. „Jana miluje Marka“). Systematicita myšlenek vychází z toho, že mentální jazyk obsahuje oddělené symboly „Marek“, „milovat“ a „Jana“, které mohou být $\mathrm{v}$ různém pořadí kombinovány do nových vět.

Mentální procesy, konkrétně myšlení, jsou pak podle Fodorova přístupu „kauzálními řetězci tokenů mentálních reprezentací. “15 Tyto mentální procesy jsou citlivé k syntaxi mentálních reprezentací, se kterými operují. Jinými slovy, inferenční pravidla jsou určována $\mathrm{v}$ syntaktických, nikoli sémantických termínech. ${ }^{16}$ Držíme-li tedy reprezentaci mající formu $P \wedge Q$, jsou mentální procesy citlivé $\mathrm{k}$ její syntaktické struktuře schopny $\mathrm{z}$ ní vyvodit reprezentaci ve formě $P$. Je-li tedy možné chápat myšlenky jako věty v hlavě, pak lze obdobně zjednodušeně popsat myšlení jako provádění logických či jiných formálních operací na těchto větách. Podobně jako v prrípadě myšlenek, rovněž i mentální procesy myšlení vykazují systematicitu nebo též inferenční koherenci. Schopnost vyvodit $P$ z $P \wedge Q$ je pak spojená se schopností provést obdobnou inferenci a vyvodit $M \mathrm{z} M \wedge N$.

Je ovšem nutné dodat, že formální procesy operující na základě syntaktické struktury mentálních reprezentací zároveň zachovávají sémantické vlastnosti těchto reprezentací. To je podle Fodora možné, protože „sémantické vlastnosti mezi symboly mohou být tak říkajíc ,napodobeny' jejich syntaktickými vztahy. ${ }^{{ }_{17}}$ Fodor v této souvislosti používá metaforu počítače

\footnotetext{
${ }^{15}$ Jerry A. Fodor, Psychosemantics: The Problem of Meaning in the Philosophy of Mind (Cambridge, MA: MIT Press, 1987), 17. Tuto i veškeré další citace cizojazyčných zdrojů přeložil autor textu.

${ }_{16}$ Michael Rescorla, „The Language of Thought Hypothesis,“ in Stanford Encyclopedia of Philosophy, accessed October 20, 2019, https://plato.stanford.edu/entries/language-thought/.

${ }^{17}$ Fodor, Psychosemantics, 19.
} 
a tvrdí, že počítač je ideální ilustrací systému, ve kterém „syntax symbolu určuje jeho kauzální roli způsobem, který respektuje jeho obsah. ${ }^{\text {“18 }}$ Příklad s počítačem tak jasně ukazuje, jak je možné spojit kauzální a sémantické vlastnosti symbolů, a to právě na základě jejich syntaxe. Zároveň pak dává odpověd” na otázku, ,jak je racionalita mechanicky uskutečnitelná “ a v konečném důsledku, „jak může být racionální myšlení výsledkem operací mozku." V tomto smyslu je tedy hypotéza jazyka myšlení úzce propojena s klasickou komputační teorií mysli. ${ }^{19}$ Mysl je totiž podle Fodora svého druhu počítačem a myšlení je komputační proces zahrnující manipulaci sémanticky interpretovatelných řetězců symbolů, které jsou zpracovány na základě formálních pravidel. ${ }^{20}$

Tento př́istup ovšem nutně vyžaduje existenci symbolických mentálních reprezentací s jak sémantickými, tak syntaktickými vlastnostmi, a tudíž i mentálního jazyka, který slouží jako médium myšlení. Jelikož pak podle Fodora většina vědeckých i laických psychologických teorií přiznaně i nepřiznaně chápe myšlení jako druh formální komputace, představuje hypotéza jazyka myšlení jediné dostupné vysvětlení kognice. ${ }^{21}$

Konečně je tř̌eba dodat, že hypotéza jazyka myšlení není pouze teorií o symbolických strukturách, ale také o jejich fyzických realizacích. Jak piší Jerry Fodor a Zenon Pylyshin, předpokládá hypotéza jazyka myšlení, že „symbolické struktury [...] korespondují s reálnými fyzickými strukturami v mozku a skladebná struktura reprezentací má protějšek v strukturálních vztazích mezi fyzikálními vlastnostmi mozku. ${ }^{22}$ Jsou to pak právě tyto neurální protějšky symbolických struktur, které zapřičiňují chování daného systému. Tímto tvrzením se hypotéza jazyka myšlení liší od jiných forem intencionálního realismu, nebot podle ní samotné „mentální stavy - a nejen pouze jejich propoziční předměty - typicky mají skladebnou strukturu. ${ }^{\text {"23 }}$

Než opustím téma jazyka myšlení, krátce se ještě pozastavím u Fodorovy charakteristiky propozičních postojů. Jejich problematika totiž představuje významnou styčnou plochu mezi kritikou jazykového pojetí kognice

\footnotetext{
${ }^{18}$ Ibid.

${ }^{19} \mathrm{~V}$ rámci tohoto článku budu pro efektivitu klasickou komputační teorii mysli a klasický komputacionismus označovat jako komputacionismus. Když tedy později stavím do protikladu komputacionismus a konekcionismus, míním tím klasický komputacionismus a konekcionistický komputacionismus.

${ }^{20}$ Schneider, „Language of Thought," 282.

${ }^{21}$ Fodor, Language of Thought; Fodor, Psychosemantics.

${ }^{22}$ Fodor and Pylyshyn, „Connectionism and Cognitive Architecture,“ 13.

${ }^{23}$ Fodor, Psychosemantics, 136.
} 
a argumentací pro eliminaci lidové psychologie, a jasně tak ukazuje vztah mezi intencionálním a větným eliminativismem. Propoziční postoje, jako jsou přesvědčení, že $P$, prání, aby $P$ či záměr, aby $P$, charakterizuje Fodor jako vztah organismu k mentální reprezentaci, která je vyjádřitelná větou $P$ v prrirozeném jazyce. Konkrétně:

Pro každý organismus $O$ a každý postoj $A$ k propozici $P$ existuje („komputační/ „funkcionální “) vztah $R$ a mentální reprezentace $M P$, takový že $M P$ znamená $P$ a $O$ zastává $A$ tehdy a pouze tehdy, když $O$ drží $R$ k $M P^{24}$

Jelikož zastávat propoziční postoj znamená být ve vztahu k mentální reprezentaci, a jak jsem ukázal výše, jsou mentální reprezentace větami jazyka myšlení, znamená zastávat propoziční postoj být ve vztahu k větě mentálního jazyka.

Vysvětlení kognice na základě mentálního jazyka a realismus vůči mentálním reprezentacím tak podle Fodora představují vědeckou obhajobu lidové psychologie. ${ }^{25}$ Toho je dosaženo právě objasněním charakteru a struktury propozičních postojů, které představují základ lidové psychologie. Spojení jazykového pojetí mysli s lidovou psychologií lze pak považovat za jednu z hlavních motivací kritiky lidové psychologie ze strany eliminativního materialismu. Tato argumentace proti sentencialismu je pozorovatelná již ve formujících textech moderního eliminativismu, ${ }^{26}$ nicméně do popředí se dostala až $\mathrm{v}$ pozdějších dílech zaměřených zejména proti hypotéze jazyka myšlení, které lidovou psychologii zmiňují spíše okrajově jako původce zakořeněných intuicí o lingvistické formě mentálních reprezentací. ${ }^{27}$

\section{Sentenciální eliminativismus a kritika jazyka myšlení}

Sentenciální eliminativismus Paula a Patricie Churchlandových předkládá řadu argumentů spojených s jazykovým pojetím kognice, jako je např́klad problematika nevyslovených přesvědčení28 nebo obecnou kritiku kompu-

\footnotetext{
${ }^{24}$ Ibid., 17.

${ }^{25}$ Ibid., 21.

${ }^{26}$ Churchland, „Eliminative Materialism,“ 82-84; Churchland, Matter and Consciousness; Churchland, Neurophilosophy.

${ }^{27}$ Patricia S. Churchland and Terrence J. Sejnowski, „Neural Representation and Neural Computation,“ Philosophical Perspectives 4 (1990): 343-82; Paul M. Churchland, „Functionalism at Forty: A Critical Retrospective,“ The Journal of Philosophy 102, no. 1 (2005): 33-50. Churchland, Plato's Camera.

${ }^{28}$ Churchland, Neurophilosophy, 390-92.
} 
tacionismu a pojetí mysli jako digitálního počítače. ${ }^{29}$ Tento oddíl se bude věnovat dvěma argumentům sentenciálního eliminativismu - problému vysvětlení charakteru myšlení mimolidských zvířat (nonhuman animals) a problému prrístupu $\mathrm{k}$ vědění (tzv. problém rámce či anglicky frame problem). Tyto problémy jsou totiž rozebírány i v pozdějších textech Churchlandových věnovaných konekcionismu, který na ně poskytuje zřejmě lepší odpovědi než komputacionismus.

\subsection{Infralingvistická katastrofa}

Jak se snaží ukázat sentenciální eliminativismus, přístup chápající myšlení jako operace v mentálním jazyce se dostává do úzkých, pokud má vysvětlit inteligentní chování tvorů bez zjevných jazykových kapacit. Tento problém označuje Patricia Churchlandová jako infralingvistickou katastrofu. ${ }^{30}$ V chování rozličných mimolidských zvířat lze identifikovat řadu kognitivních výkonů vyžadujících podstatnou míru vhledu, plánování a koordinace. Jako př́klady lze uvést například orangutany vytvářející si deštníky z listů, bobry stavějící hráz, lovící lví smečku, anebo dokonce chobotnici schopnou otevř́ít zavařovací sklenici s potravou. ${ }^{31}$ Všechny tyto prŕklady lze chápat jako ukázky inteligentního chování, které je výsledkem myšlenkových procesů. Pro hypotézu jazyka myšlení zde tedy vyvstává otázka, jaké povahy jsou tyto procesy a zda tvorům nevládnoucím veřejným jazykem přisoudit soukromý jazyk myšlení.

Jednou z možných odpovědí na tuto otázku je, že tyto organismy nemají mentální jazyk a jejich chování není výsledkem kognice. Alespoň v tom smyslu, jak chápeme kognici lidskou. Jelikož je myšlení charakterizováno jako (logické) operace $\mathrm{v}$ mentálním jazyce, jakékoli procesy zakládající zvírecí „myšlení“, které nemají jazykovou strukturu, nemohou být $z$ definice chápány jako kognitivní. ${ }^{32}$ Tento přístup by však musel zodpovědět problematickou otázku, proč i navzdory tomu, že vnitřní procesy těchto tvorů nejsou lingvistické a tedy kognitivní, jsme schopni úspěšně popisovat

\footnotetext{
${ }^{29}$ Churchland, Matter and Consciousness; Churchland and Sejnowski, „Neural Representation“; Patricia S. Churchland, Brain-Wise: Studies in Neurophilosophy (Cambridge, MA: MIT Press, 2002), 284-85.

${ }^{30}$ Churchland, Neurophilosophy, 388-89.

${ }^{31}$ Viz Churchland, Neurophilosophy; Paul M. Churchland, "The Evolving Fortunes of Eliminative Materialism,“ in Contemporary Debates in Philosophy of Mind, eds. Brian P. McLaughlin and Jonathan D. Cohen (Malden, MA; Oxford: Blackwell, 2007), 160-81.

${ }^{32}$ Churchland, Neurophilosophy, 389.
} 
tyto procesy za pomoci propozičních postojů lidové psychologie, jako jsou přesvědčení, že $P$, přání, aby $P$, záměr, aby $P$, a další. Jinými slovy, proč popisujeme nekognitivní aktivitu zvířat jako kognitivní, a především proč je takovýto popis predikčně úspěšný.

Rovněž problematický je i předpoklad, že zvířecí „myšlení“ je výsledkem zcela odlišných procesů než myšlení lidské. To by znamenalo, že v evoluci lidské kognice existuje radikální diskontinuita ve vztahu ke zbytku zvírecí říše. Jazyku podobná kognice by se $\mathrm{v}$ tomto případě $\mathrm{v}$ rámci lidského vývoje zjevila bez žádného zjevného předchůdce $\mathrm{v}$ „,kognitivních“ procesech našich evolučních předků. To by ovšem v mnohém odporovalo předpokladům evoluční biologie, že v mozku coby produktu evoluce lze nalézt četné podobnosti a kontinuity mezi způsoby reprezentací a myšlení u lidí a ostatních zvírat. ${ }^{33}$ Takový př́stup je tedy udržitelný jen za cenu, že prohlásíme podstatnou část evoluční biologie a vývojové neurobiologie za chybnou, což je důsledek, který lze považovat za jak nežádoucí, tak nepravděpodobný. ${ }^{34}$

Další možností je pak prohlásit, že i u tvorů nevládnoucích jazykem se jedná o kognici stejného druhu jako u lidí, a přiznat jazyk myšlení i mimolidským zvířatům. Tento názor lze nalézt rovněž u Jerryho Fodora. ${ }^{35}$ Takové chápání zvířecí kognice ovšem podle Churchlandových postrádá potřebnou empirickou evidenci. ${ }^{36}$ Navzdory tomu, že by zvířecí myšlení mělo probíhat v soukromém mentálním jazyce, nevykazují zvířata ve větší míre schopnost zacházet $s$ žádným veřejným jazykem. Na určité úrovni jsou toho schopni šimpanzi a jiné vyšší opice, ${ }^{37}$ avšak jak piše Churchland, i schopnosti dospělých šimpanzů jsou překonány lidskými dětmi již ve dvou letech. ${ }^{38}$ Vyvstává tedy otázka, proč - pokud je myšlení logickým zřetězením propozičních postojů - nejsou zvíŕata schopna veřejné produkce propozic. Dalo by se očekávat, že pokud všichni kognitivní tvorové disponují mentálním jazykem, měli by být lépe schopni používat veřejný jazyk se skladebnou strukturou obdobnou jejich mentálním procesům. Zjednodušeně: Pokud zvířata myslí $\mathrm{v}$ médiu jazyka, proč v něm nejsou schopna komunikovat?

$\mathrm{Na}$ základě těchto úvah dochází sentenciální eliminativismus k závěru, že hypotéza jazyka myšlení pravděpodobně nepředstavuje vhodné vysvět-

\footnotetext{
${ }^{33}$ Churchland, Brain-Wise, 283.

${ }^{34}$ Churchland and Sejnowski, „Neural Representation,“ 355.

${ }^{35}$ Fodor, Language of Thought, 55-59.

${ }^{36}$ Churchland and Sejnowski, „Neural Representation“; Churchland, „Evolving Fortunes.“

${ }^{37}$ Paul M. Churchland, The Engine of Reason, the Seat of the Soul: A Philosophical Journey into the Brain (Cambridge, MA: MIT Press, 1996), 257-64.

${ }^{38}$ Churchland, „Evolving Fortunes.“
} 
lení zákonitostí mysli - zvířecí ani lidské. Namísto toho nabízí hypotézu, podle níž se kognitivní procesy nelingvistických zviŕat neodehrávají v mentálním jazyce, ale ani se radikálně neliší od lidských. ${ }^{39}$ Podle tohoto př́stupu jsou kognitivní schopnosti lidí i zviřat výsledkem fundamentálnějších neurálních procesů, které sice lze vyjádřit $\mathrm{v}$ jazyce, ale které samy nemají jazykovou povahu. Takové pojetí kognice by zajistilo evoluční kontinuitu mezi schopnostmi lidí a ostatních zvířat, ale nikoli za cenu nedostatečně podloženého přisouzení jazyka myšlení zvířatům. Tímto lidem i ostatním zvířatům společným mechanismem zakládajícím kognici má být právě konekcionistické, paralelně distribuované zpracování informací.

\subsection{Problém př́istupu $k$ vědění}

Dalším významným problémem sentencialismu je přístup k vědění. Sentencialistické pojetí mysli totiž čelí otázce, jak mohou být systémy ukládající informace pomocí sady propozic schopny ve svém úložišti vědomostí (knowledge store) nalézt v krátkém čase relevantní informace pro řešení konkrétních problémů. Jinými slovy, jak jsou tyto systémy schopny abduktivního usuzování. Problém abdukce, označován též jako problém rámce, byl původně formulován v rámci výzkumu umělé inteligence. ${ }^{40}$ Do filosofie byl poprvé zaveden Danielem Dennettem ${ }^{41}$ a následně se stal významným argumentem proti klasické komputační teorii mysli.

V článku „Cognitive Wheels: The Frame Problem of AI ${ }^{\text {‘42 }}$ ilustruje Dennett problém rámce na příkladu robotů jednajících na základě instrukcí, které mají podobu vět uložených v jejich programu. Dennett zde ukazuje, jak je pro systémy ukládající informace takovým způsobem obtížné až nemožné vykonávat dokonce i prosté úkony v prostředí, které svým jednáním mění. Takové systémy totiž postrádají schopnost, jak ve svém propozičním úložišti

\footnotetext{
${ }^{39}$ Viz Churchland, Brain-Wise; Churchland, „Evolving Fortunes“; Churchland, Plato’s Camera.

${ }^{40}$ John McCarthy and Patrick J. Hayes, „Some Philosophical Problems from the Standpoint of Artificial Intelligence, “in Machine Intelligence: No. 4, eds. Bernard N. Meltzer and Donald Michie (Edinburgh: Edinburgh University Press, 1969). Viz též Murray Shanahan, „The Frame Problem," in Stanford Encyclopedia of Philosophy, accessed October 20, 2019, https://plato. stanford.edu/entries/frame-problem/.

${ }^{41}$ Daniel C. Dennett, „Artificial Intelligence as Psychology and as Philosophy, “in Brainstorms: Philosophic Essays on Mind and Psychology (Montgomery, VT: Bradford Books, 1978), 109-26. ${ }^{42}$ Daniel C. Dennett, „Cognitive Wheels: The Frame Problem of AI,“ in Minds, Machines, and Evolution: Philosophical Studies, ed. Christopher Hookway (Cambridge: Cambridge University Press, 1986).
} 
vědomostí za různých podmínek spolehlivě zohlednit, co je třeba zohlednit, a ignorovat to, co je třeba ignorovat. Následkem toho pak nejsou schopni aktualizovat svá přesvědčení o světě tak, aby tato přesvědčení odpovídala stavu světa, který svým jednáním mění.

Jak píše Fodor, tito roboti a jim podobné reprezentační systémy nedokáží provádět abduktivní odvození, která jsou spolehlivá a zároveň proveditelná. ${ }^{43}$ Proveditelná abdukce dovoluje kontrolu pouze omezeného množství přesvědčení o světě. Takové usuzování je ovšem v neustálém nebezpečí, že opomene nějakou důležitou informaci pro danou situaci. Na druhou stranu spolehlivá abdukce $\mathrm{v}$ zásadě vyžaduje zohlednit veškerá přesvědčení o světě, která daný kognitivní systém drží. Neexistuje jasné kritérium určující, které a pouze které informace jsou pro libovolnou danou situaci podstatné. ${ }^{44}$ Relevantní informace může přijít $\mathrm{z}$ jakéhokoli místa $\mathrm{v}$ síti přesvědčení, a spolehlivé abduktivní usuzování tak musí zohlednit všechna přesvědčení daného systému. To by ovšem pro kognitivní systémy, jejichž přesvědčení mají charakter propozic, znamenalo obrovskou komputační zátěž, a nutně tak vedlo k jejich zahlcení obrovským množstvím irrelevantních informací.

Selhání robotů z Dennettova př́kladu představují závažný problém nejen pro výzkum umělé inteligence, ale především pro pojetí mysli jako komputací v mentálním jazyce. Slovy Jerryho Fodora: „Selhání umělé inteligence je v podstatě selháním klasické komputační teorie mysli fungovat v praxi. ${ }^{45}$ Toto selhání je o to zřejmější, zvážíme-li, že lidé se ve svém jednání s problémem rámce nepotýkají. Vaření kávy nebo příprava půlnoční svačinky po nás každodenně vyžadují obdobné zvažování vedlejších následků a aktualizaci stávajících přesvědčení jako výše popsaná experimentální situace s roboty. Přesto však tyto činnosti vykonáváme rychle, spolehlivě a bez vynaložení většího kognitivního úsilí.

Problémy spojené s chováním robotů a jejich absence u lidí a jiných živočichů vedly Dennetta i Churchlandovi k závěru, že lidské zásobárny vědění nejsou organizovány jako sady vět a že myšlení nemá charakter komputací na jazykových reprezentacích. ${ }^{46}$ Paul a Patricia Churchlandovi

\footnotetext{
${ }^{43}$ Jerry A. Fodor, The Mind Doesn't Work That Way: The Scope and Limits of Computational Psychology (Cambridge, MA: MIT Press, 2000), 37-39.

${ }^{44}$ Ibid., 38.

${ }^{45}$ Ibid.

${ }^{46}$ Viz Dennett, „Cognitive Wheels: The Frame Problem of AI“; Churchland, Neurophilosophy; Paul M. Churchland, "On the Nature of Theories: A Neurocomputational Perspective," in A Neurocomputational Perspective: The Nature of Mind and the Structure of Science (Cambridge, MA: MIT Press, 1992), 153-96; Shanahan, „Frame Problem.“
} 
pak jako alternativu $\mathrm{k}$ tomuto pojetí mysli zatíženému problémem rámce navrhují prŕstup konekcionismu, který se podle jejich názoru s tímto problémem nepotýká.

\section{Konekcionistické pojetí mysli}

Když Jerry Fodor v roce 1975 představoval hypotézu jazyka myšlení, argumentoval pro nutnost mentálního jazyka tím, že jediné vzdáleně plauzibilní vysvětlení kognice je formální komputace s vnitřními symboly, které mají jazykovou povahu. Skutečně lze tvrdit, že jazyk po dlouhou dobu představoval jediný dostupný systematický reprezentační systém a klasický komputacionismus spolu s jazykem myšlením zas jediný dostupný model mysli. Jak píše Patricia Churchlandová, věty jako lingvistické entity byly a jsou stále široce chápány jako prototyp skutečných reprezentací, s nimiž jsou ostatní potenciální reprezentace poměřovány. ${ }^{47}$ Tato situace se ovšem do jisté míry změnila $\mathrm{s}$ rostoucím zájmem o zkoumání neuronových sítí a konekcionistických reprezentací, které začaly být vnímány jako alternativa či dokonce konkurence klasického komputačního pojetí. ${ }^{48}$ Konekcionismus se záhy stal předmětem zájmu moderních eliminativních materialistů, kteří jej brali jako zásadní argument proti propozičním postojům a je zastřešující lidové psychologii. ${ }^{49}$ Od devadesátých let se pak konekcionismus a jeho dopady pro chápání mysli staly jedním z hlavních témat prací Paula a Patricie Churchlandových. ${ }^{50}$ Eliminativní materialismus, minimálně v jejich podání, se tak začal značně prolínat se sporem mezi komputacionismem a konekcionismem. ${ }^{51}$

${ }^{47}$ Churchland, Brain-Wise, 274.

${ }^{48}$ Viz Rescorla, „Language of Thought Hypothesis“; David E. Rumelhart, James L. MacClelland, and PDP Research Group, Parallel Distributed Processing. Explorations in the Microstructure of Cognition: Volume 1: Foundations (Cambridge, MA: MIT Press, 1986).

${ }^{49}$ Viz William M. Ramsey, Stephen Stich, and Joseph Garon, „Connectionism, Eliminativism and The Future of Folk Psychology,“ Philosophical Perspectives 4 (1990): 499-533; Churchland and Sejnowski, „Neural Representation“; Paul M. Churchland, A Neurocomputational Perspective: The Nature of Mind and the Structure of Science (Cambridge, MA: MIT Press, 1992).

${ }^{50}$ Viz Patricia S. Churchland and Terrence J. Sejnowski, The Computational Brain (Cambridge, MA: MIT Press, 1996); Churchland, Engine of Reason; Churchland, Brain-Wise; Churchland, Plato's Camera.

${ }^{51}$ Spor konekcionismu a komputacionismu zůstává dodnes otevřenou debatou, jejíž analýza by značně přesáhla rozsah tohoto článku. V následné argumentaci se tedy nebudu zabývat důkazy pro platnost konekcionismu, ale omezím se pouze na představení kondicionálního tvrzení, že pokud se mozek a mysl řídí stejnými principy jako jednodušší neuronové sítě, znamená to 
Konekcionistické sítě52 se zpravidla skládají z velkého počtu jednotek (neuronů, uzlů) vzájemně propojených synapsemi, které mají určitou numerickou sílu nebo váhu. Tyto váhy určují hodnotu impulzu, jakým jedna jednotka působí na druhou. Neuronová sít má zpravidla tři úrovně - úroveň vstupních neuronů, úroveň skrytých (pracovních) neuronů a úroveň výstupních neuronů. Složitější sítě mohou mít libovolně vysoký počet takových řad. Stejně tak mohou variovat počty jednotek $\mathrm{v}$ jednotlivých řadách. Kdybychom chtěli dělat paralelu s biologickým organismem, vstupní jednotky by odpovídaly smyslovým neuronům, skryté jednotky neuronům mozku a výstupní jednotky nakonec motorickým neuronům. ${ }^{53}$

Každá vstupní jednotka neuronové sítě má aktivační hodnotu, která reprezentuje nějakou vlastnost mimo sít. Na základě své aktivační hodnoty posílá signály výše do skrytých jednotek. Skryté jednoty na základě získaných impulzů nastavují své vlastní aktivační hodnoty a posílají signály do další řady skrytých jednotek nebo do koncové úrovně. Když signál projde celou sítí, určí hodnoty jednotlivých výstupních jednotek. Zde jej lze znázornit jako jednoduchý aktivační vektor (uspořádanou množinu čísel znázorňující aktivační hodnoty jednotlivých neuronů).

Komputace v neuronových sítích má tedy podobu výše popsané transformace aktivačních vektorů. K té dochází právě projekcí jednoho aktivačního vektoru skrze matici synaptických spojení (mezi skrytými neurony) vedoucí ke vzniku nového aktivačního vektoru v jiné populaci koncových neuronů.

Významnou vlastností mnohých konekcionistických sítí je jejich schopnost učení. Takové sítě de facto programují samy sebe skrze autonomní procedury (algoritmy), kterými nastavují své synaptické váhy tak, aby byly schopny vykonávat daný úkol. Pro jejich trénink jsou sítím zpravidla poskytnuty pouze páry vstupů a výstupů procedury, kterou mají vykonávat. $\mathrm{Na}$ základě těchto párů sít pomocí učících algoritmů postupnými kroky určí optimální nastavení svých synaptických vah pro výkon daného úkolu.

špatné zprávy pro pojetí mysli jako počítače, provádějícího formální operace na symbolech mentálního jazyka. Pro obecný přehled diskuse viz Michael Rescorla, „The Computational Theory of Mind," in Stanford Encyclopedia of Philosophy, accessed October 20, 2019, https://plato.stanford.edu/entries/computational-mind/; James Garson, „Connectionism, “ in Stanford Encyclopedia of Philosophy, accessed October 20, 2019, https://plato.stanford.edu/ entries/connectionism/; Rescorla, „Language of Thought Hypothesis.“

${ }_{52}$ Při tomto popisu neuronových sítí a jejich principů vycházím primárně ze Smolenského článku z roku 1988, který doplňuji o popis z Brain-Wise P. Churchlandové a Gorsonova textu na SEP. Viz Paul Smolensky, „On the Proper Treatment of Connectionism,“ Behavioral and Brain Sciences 11, no. 1 (1988): 1-23; Churchland, Brain-Wise; Garson, „Connectionism.“

${ }_{53}$ Tato paralela je přejata z Garson, „Connectionism.“ 
Zde je třeba dodat, že aktivační úroveň jednotlivých neuronů není při učení nikdy měněna prrímo, ale pouze skrze upravování synaptických vah. Jsou to tedy synaptické váhy, které slouží k ukládání vědění neuronové sítě.

Uvedený popis struktury a funkcí neuronových sítí představuje podstatně zjednodušený model. Komplexnější sítě chovající se podle výše uvedených principů, které eliminativní materialisté používají jako př́iklady, jsou nicméně schopny předvádět poměrně komplexní kognitivní výkony. Umělé neuronové sítě dovedou např́íklad předčítat anglický text ${ }^{54}$ nebo rozpoznávat pohlaví a jména obličejů na fotografiích. ${ }^{55}$

\subsection{Spor konekcionismu a komputacionismu}

Po obecném představení základů struktury a funkční dynamiky neuronových sítí se nyní zaměřím na některé jejich aspekty, které podle eliminativního materialismu staví konekcionismus do protikladu s komputacionismem a jazykovým pojetím mysli. Bude to jednak rozdíl v povaze symbolů a jednak rozdíl $v$ povaze komputačních procesů.

Za prvé: v neuronových sítích se nevyskytují jednoduché izolovatelné symboly odpovídajícím atomickým symbolům mentálního jazyka, který předpokládá komputacionismus. Pro lepší pochopení tohoto tvrzení je třeba rozlišit mezi dvěma způsoby kódování v neuronových sítích - lokálním a distribuovaným.

V lokálně kódujících sítích stojí jednotlivé jednotky v poměru jedna ku jedné $\mathrm{k}$ reprezentovaným vlastnostem mimo sít. Neuron reprezentující naši babičku by se tak aktivoval vždy v moment, kdy bychom mysleli na naši babičku. Ač lokální kódování představuje adekvátní nástroj pro některé jednodušší případy, je tento př́stup až př́liš zjednodušující a nevhodný pro složitější situace a problémy vyžadující vyšší množství reprezentací. ${ }^{56}$ Lokální kódování je pak obzvláště nevhodné pro model lidské kognice, nebot počet potřebných reprezentací by značně převýšil množství v mozku dostupných neuronů. ${ }^{57} \mathrm{Z}$ tohoto důvodu je obecně preferován spíše př́istup

\footnotetext{
${ }^{54}$ Terrence J. Sejnowski and Charles R. Rosenberg, „Parallel Networks that Learn to Pronounce English Text, “ Complex Systems 1, no. 1 (1987): 145-68.

${ }^{55}$ Garrison W. Cottrell, „Extracting Features From Faces Using Compression Networks: Face, Identity, Emotion, and Gender Recognition Using Holons," in Connectionist Models, eds. David S. Touretzky et al. (San Francisco: Morgan Kaufmann, 1991), 328-37.

${ }^{56}$ Churchland and Sejnowski, Computational Brain, 129-45; Churchland, Brain-Wise, 28993; Garson, „Connectionism.“

${ }^{57}$ Churchland, Brain-Wise, 289.
} 
distribuovaného kódování, které je rovněž vhodnější pro modelování lidské kognice.

Distribuované (vektorové) kódování nereprezentuje vlastnosti mimo sít jednotlivými neurony, ale specifickými vzory aktivity např́č většími populacemi neuronů. Základní jednotky takových sítí tedy nejsou symbolické, ale zastávají spíše subsymbolickou roli. To znamená, že žádný jednotlivý neuron nikdy sám nereprezentuje jednotlivou vlastnost mimo sít. Zároveň pak bývají neurony součástí více rủzných populací a hrají tak roli v řadě rozdílných reprezentací.

Sítě reprezentující za pomoci distribuovaného kódování tak nemají diskrétní vlastnosti, které by šlo systematickým způsobem interpretovat jako reprezentace propozic. William Ramsey a kol. to demonstrují na př́kladu $\mathrm{s}$ jednoduchou dopřednou neuronovou sítí (sít A). ${ }^{58}$ Sít A z daného př́kladu byla vytrénována $\mathrm{k}$ určení pravdivosti souboru šestnácti vět. ${ }^{59}$ Síti byl poskytnut soubor správných vstupů a výstupů požadovaného úkonu, na jehož základě byly nastaveny synaptické váhy sítě určující aktivaci jednotlivých neuronů. Trénink sítě byl zastaven, když byla sít schopna konzistentně určovat pravdivost vět $s$ úspěšností $90 \%$. Sít A tak ukládala pravdivostní hodnoty sady šestnácti vět. Jak ovšem Ramsey a kol. upozorňují, neměla tato sít žádnou rozlišitelnou část, kterou by šlo identifikovat $s$ jednou ze souboru reprezentovaných vět. Tento problém autoři dále ilustrují prríkladem druhé sítě (sít B). Sít B byla trénována stejným způsobem jako původní sít A na témže souboru šestnácti vět plus jedné přidané. Tento rozdíl $v$ informacích uložených $\mathrm{v}$ obou sítích se projevil v mnoha aspektech např́íc všemi jednotkami sítí. Jak ovšem píší Ramsey a kol., tyto jejich rozdíly nebylo možné systematicky korelovat s diskrétními a sémanticky interpretovatelnými jednotkami, které předpokládají klasické modely kognice. Sítě „postrádají funkčně odlišitelné, identifikovatelné substruktury, které jsou sémanticky interpretovatelné jako reprezentace jednotlivých propozic. ${ }^{\text {" }} 0$

$S$ výše zmíněným rovněž souvisí další podstatný rozdíl konekcionismu a klasických př́stupů, totiž že neuronové sítě ukládají informace holisticky napříc velkými populacemi neuronů. To znamená, že se v nich nevyskytuje oddělená zásobárna vědění, jak je tomu v př́padě digitálních počítačů a jak předpokládá klasický komputacionismus. Informace jsou namísto toho

\footnotetext{
${ }^{58}$ Ramsey, Stich, and Garon, „Connectionism.“

${ }^{59}$ Jednalo se vždy o jednoduché věty se stejnou strukturou, jako např.: Psi mají srst; kočky mají tlapky; ryby mají šupiny; psi mají šupiny; ryby mají blechy apod.

${ }^{60}$ Ramsey, Stich, and Garon, „Connectionism,“ 514.
} 
ukládány např́ič sítí v nastavení synaptických vah, tedy ve stejném médiu, v jakém dochází ke komputacím. ${ }^{61}$

Za druhé: komputace v neuronových sítích nemají podobu logicky-formálních operací. Kromě toho, že se v sítích nevyskytují diskrétní sémanticky interpretovatelné symboly, na nichž by tyto operace byly prováděny, mají samotné komputace charakter transformace aktivačních vektorů projekcí naprríč populacemi neuronů, které nejsou řízeny formálními pravidly. Neuronové sítě zpracovávají informace nelineárně dynamickými procesy ve vývoji aktivačních potenciálů vzájemně propojených populací neuronů. ${ }^{62}$ Tyto komputace jsou ovlivněny pouze silami jednotlivých synaptických vah a nikoli pravidly pro manipulaci se symboly. ${ }^{63}$ Takové pojetí mentálních procesů je opět jen málo podobné zřetězení mentálních symbolů vytvořeným na základě formálních pravidel, které tvoří základ kognice podle klasického komputacionismu a hypotézy jazyka myšlení.

Konekcionismus je tedy významnou antitezi komputacionismu a hypotézy jazyka myšlení. Pro eliminativní materialismus pak představuje důležitý argument proti lidové psychologii, nebo alespoň proti lingvistickému pojetí kognice, které je lidové psychologii přisuzováno. Toto stanovisko asi nevýstižněji shrne citace Paula Churchlanda:

Jak se zřetelně ukazuje, je u lidí a zvířat obecně, základní jednotkou kognice aktivační vektor. Je rovněž zřejmé, že základní jednotkou komputace je transformace vektorů. A je evidentní, že základní jednotkou paměti je konfigurace synaptických vah. Žádná $z$ těchto věcí nemá zásadně co dočinění s větami, propozicemi nebo inferenčními vztahy mezi nimi. Naše tradiční na jazyk orientovaná koncepce kognice je nyní konfrontována s velmi odlišnou na mozek orientovanou koncepcí. Takovou, která jazyku nepřisuzuje žádnou fundamentální roli. ${ }^{64}$

Jsou to tedy distribuované procesy neuronových sítí, které podle Churchlandových představují základní sublingvistickou úroveň kognice. Je to tato sublingvistická úroveň, která zakládá všechny složitější mentální stavy. Jelikož se pak mysl na své základní úrovni řídí konekcionisitickou dynamikou, nepředstavují manipulace s diskrétními symboly a mentální ja-

\footnotetext{
${ }^{61}$ Viz Churchland and Sejnowski, „Neural Representation.“

${ }^{62}$ Ibid.; Garson, „Connectionism.“

${ }^{63}$ Smolensky, „On the Proper Treatment of Connectionism.“

${ }^{64}$ Churchland, Engine of Reason, 322-23.
} 
zyk, který tyto symboly poskytuje, adekvátní popis mechanismů mentálních procesů.

Je potřeba dodat, že Churchlandovi a další eliminativní materialisté vychází z radikální interpretace konekcionismu jako přístupu konkurujícímu komputacionismu. ${ }^{65}$ Konekcionismus bývá někdy chápán jako popis nižších úrovní kognice, který není ve sporu s popisem vyšších psychologických úrovní za pomoci manipulace se symboly. Konekcionismus je naopak takovým přístupem brán jako možné znázornění způsobu, jak jsou tyto psychologické procesy fyzicky implementovány na nižší úrovni organizace. ${ }^{66}$ Toto pojetí konekcionismu je churchlandovským eliminativním materialismem odmítáno. Jak lze vidět výše, představuje podle něj konekcionismus alternativní paradigma ke klasickému komputacionismu, se kterým je v přímém rozporu. Pokud je tedy mozek neuronovou sítí chovající se obdobným způsobem jako jednodušší neuronové sítě v konekcionistických experimentech, jsou komputacionismus a předpoklad jazyka myšlení neadekvátními a chybnými znázorněními kognice.

Než postoupím dál, budu se krátce věnovat otázce systematicity, produktivity a inferenčí koherence. V roce 1988 předložili Jerry Fodor a Zenon Pylyshyn významnou kritiku konekcionismu postavenou právě na těchto vlastnostech myšlení. ${ }^{67}$ Konekcionismus podle jejich argumentu není schopný podat vysvětlení systematicity, produktivity a inferenční koherence, aniž by se nestal implementací klasické konekcionistické architektury kognice. Churchlandovi se do debaty spojené s problémem systematicity, produktivity a inferenční koherence téměř nezapojují, což lze vnímat jako nedostatek jejich argumentace proti sentencialismu. I přes relativní skromnost zdrojů je ovšem možné sestavit alespoň částečnou reakci na tyto námitky proti konekcionismu. $\mathrm{O}$ to se pokusím $\mathrm{v}$ následujících několika odstavcích, než se obrátím $\mathrm{k}$ tomu, jak konekcionismus odpovídá na dříve představené problémy sentencialistického modelu.

Nemyslím si, že jejich mlčení je způsobeno tím, že by churchlandovský eliminativismus popíral existenci mentálních reprezentací jako takových, čímž tento argument proti konekcionismu odstraňují v samém počátku, jak píše Michael Rescorla. ${ }^{68}$ Jak se v tomto článku snažím ukázat, Churchlan-

\footnotetext{
${ }^{65}$ Viz Churchland and Sejnowski, „Neural Representation“; Churchland, A Neurocomputational Perspective; Ramsey, Stich, and Garon, „Connectionism.“

${ }^{66}$ Viz Fodor and Pylyshyn, „Connectionism and Cognitive Architecture.“

${ }^{67}$ Ibid.

${ }^{68}$ Rescorla, „Language of Thought Hypothesis.“
} 
dovi a další eliminativní materialisté odmítají pouze určitý druh mentálních reprezentací, a totiž jazykově strukturovaných propozičních postojů. ${ }^{69}$

V knize The Engine of Reason, The Seat of The Soul se Paul Churchland krátce věnuje otázce gramatické produktivity neuronových sílí. ${ }^{70}$ Uvádí zde př́ílad neuronové sítě, která byla schopna vykazovat určitou míru gramatické produktivity. I když tato schopnost neuronové sítě nedosahovala rozsahu běžného mluvčího angličtiny, ukazuje podle Churchlanda tento příklad, že je principiálně možné, aby neuronové sítě byly schopné gramatické produktivity.

V odpovědi na námitky Jerryho Fodora z roku 1996 se pak Churchland přiklání $\mathrm{k}$ řešení, které Paul Smolensky předložil v reakci na Fodorovu a Pylyshynovu argumentaci proti konekcionismu za pomoci systematicity a produktivity. ${ }^{71}$ Smolensky zde navrhuje interpretace konekcionistických reprezentací, které v distribuované podobě vykazují jistou formu skladebné struktury potřebné pro zodpovězení Fodorovy a Pylyshynovy námitky. Tyto reprezentace podle Smolenského postrádají jednoduché části předpokládané komputacionismem, ale jsou rozložitelné na reprezentace dílčích elementů složitějších reprezentací. ${ }^{72}$

\subsection{Konekcionistické řešení sentencialistických problémů}

Nyní, po stručném představení role konekcionismu v argumentaci eliminativního materialismu a jeho vztahu $\mathrm{k}$ jazyku myšlení, se krátce vrátím k otázkám infralingvistické katastrofy a problému rámce a pokusím se ukázat, jak na ně lze odpovědět z pozice konekcionismu.

${ }^{69}$ Churchland, Plato's Camera, 131-32; Ramsey, Stich, and Garon, „Connectionism.“

${ }^{70}$ Churchland, Engine of Reason, 136-43.

${ }^{71}$ Paul M. Churchland, "Connectionism as Psychology, in The Churchlands and Their Critics, ed. Robert N. McCauley (Blackwell, 1996), 234. Viz Paul Smolensky, „Tensor Product Variable Binding and the Representation of Symbolic Structures in Connectionist Systems, “ Artificial Intelligence 46, no. 1-2 (1990): 159-216; Paul Smolensky, „Connectionism, Constituency and the Language of Thought, “ in Meaning in Mind: Fodor and His Critics, eds. Barry M. Loewer and Georges Rey (Oxford: Blackwell, 1991).

${ }^{72}$ Smolensky, „Connectionism, Constituency and the Language of Thought.“ Bližší specifika Smolenského návrhu a následná dosud otevřená diskuse o jeho adekvátnosti do značné míry přesahuje rozsah a záměry této práce. Viz též Jerry Fodor and Brian P. McLaughlin, "Connectionism and the Problem of Systematicity: Why Smolensky's Solution Doesn't Work," Cognition 35, no. 2 (1990): 183-205. 


\subsubsection{Infralingvistická katastrofa}

Podle Paula Churchlanda je konekcionistické vysvětlení mysli významné mimo jiné i proto, že ,je $\mathrm{v}$ kontaktu s fyzickými a funkčními detaily biologického orgánu (mozku), který skutečně zakládá naši kognitivní aktivitu." ${ }^{\text {"73 }}$ $\mathrm{V}$ tomto ohledu pak konekcionismus představuje kontinuální vysvětlení lidské a zvířecí kognice, nebot je pravděpodobné, že mozek jako produkt evoluce bude vykazovat významné fyzické a funkční podobnosti a kontinuity mezi zakládáním kognice lidí a zvírat. Konekcionismus se tak při vysvětlování kognice organismů nevládnoucích veřejným jazykem nemusí potýkat $s$ obdobnými problémy jako sentencialismus a $\mathrm{k}$ infralingvistické katastrofě u něj v podstatě nedochází. Konekcionistický model nepředpokládá jazykový základ kognice, jehož existence či absence by u zvírat př́edstavovala problém. Naopak, konekcionismem předkládaná sublingvistická úroveň kognice představuje jednotný, evolučně kontinuální základ myšlení lidí i zvírat.

Nabízí se samozřejmě otázka, nakolik je takové znázornění funkční dynamiky neurálních procesu přesné a nakolik jsou biologicky inspirované umělé neuronové sítě skutečně biologicky realistické. Často vyzdvihovanou vlastností neuronových sítí je jejich pozvolné degradování. Neuronové sítě jsou relativně odolné vůči poškození, a i při ztrátě některé jejich části jsou schopné vykonávat dané funkce, které degradují postupně na rozdíl od počítačů, které degradují náhle. $\mathrm{V}$ tomto ohledu jsou biologicky realistické a podobné mozku, jehož funkce jsou rovněž poměrně odolné vůči poškození, nemocem a degeneraci stárnutím. ${ }^{74}$

$\mathrm{Na}$ druhou stranu se umělé neuronové sítě od vnitřního uspořádání biologického mozku pochopitelně v řadě aspektů odlišují. Liší se tak např́íklad množstvím spojů jednotlivých neuronů ${ }^{75}$ učícími algoritmy, které používají ${ }^{76}$ nebo způsobem propojení sítě. ${ }^{77}$ Asi nejvýznamnější rozdíl mezi umělými sítěmi a mozkem je pak samozřejmě velikost a rozsah vykonávaných funkcí. Umělé neuronové sítě jsou oproti biologickému mozku zpravidla

\footnotetext{
${ }^{73}$ Churchland, Plato's Camera, 14.

${ }^{74}$ Churchland, „On the Nature of Theories,“ 178-79.

${ }^{75}$ Biologické neurony jsou zpravidla propojeny řidčeji než umělé neurony, které bývají spojeny synapsí s každým jednotlivým neuronem na vyšší i nižší úrovni sítě. Churchland, Plato’s Camera, 161-62.

${ }^{76}$ Churchland, „On the Nature of Theories.“

77 Umělé neuronové sítě bývají zpravidla dopředné, zatímco u mozku lze předpokládat cyklickou, rekurentní strukturu, kde mohou impulzy rovněž sestupovat z vyšších či koncových úrovní na nižší. Viz Churchland, Plato’s Camera; Garson, „Connectionism.“
} 
mnohonásobně menší a zaměřuií se na vykonávání jedné konkrétní funkce. Lze nicméně předpokládat, že principy vyskytující se $\mathrm{v}$ těchto jednodušších sítích se budou vyskytovat rovněž u složitějších sítí a v konečném důsledku i v mozku. Umělé neuronové sítě, o něž se v argumentaci opírá eliminativní materialismus, nejsou zdaleka schopny reprodukovat veškerou aktivitu mozku. Přinášejí ovšem důležité první biologicky plausibilní přiblížení tomu, jak by mohl mozek ve skutečnosti reprezentovat svět a vykonávat některé kognitivní úkony.

\subsubsection{Problém prístupu $k$ vědění}

Podobně jako tomu bylo $\mathrm{v}$ př́ípadě infralingvistické katastrofy, mizí v konekcionismu i problém rámce a problematika abduktivního usuzování. Na rozdíl od sentencialistických systémů neukládají neuronové sítě vědění v dlouhém seznamu vět, který je nutné postupně kontrolovat pro relevantní informaci. Namísto toho jsou informace $\mathrm{v}$ neuronových sítích ukládány v konfiguraci synaptických vah např́íc celou sítí. Při zpracovávání stimulů a vyvozování jsou pak všechny tyto synaptické váhy (a tedy všechny informace obsažené sítí) kauzálně aktivní současně. ${ }^{78} \mathrm{~V}$ neuronových sítích tedy nedochází k prohledávání jednotlivých propozic. Sít je namísto toho "globálně citlivá “ ke všem informacím v ní uložených. ${ }^{79}$

Paul Churchland tvrdí, že v konekcionistickém př́stupu lze „inferenci $\mathrm{k}$ nejlepšímu vysvětleni“ přeformulovat jako „aktivaci nejvhodnějšího prototypu aktivačního vektoru. ${ }^{\text {"80 }}$ Takovou aktivaci ovšem správně vytrénovaná sít vykonává automaticky a přímo. Jedná se pravděpodobně o základní formu procesu v neuronových sítích a mozku. ${ }^{81}$ Správně vytrénovaná sít v reakci na daný stimul (vektor na vstupní úrovni neuronů) aktivuje skrze zpracování např́č skrytými jednotkami adekvátní aktivační vektor na výstupní úrovni. Toto zpracování vstupního stimulu je určeno holisticky rozložením synaptických vah napříč sítí, které ukládá vědění obsažené v síti a které bylo určeno při jejím trénování.

Usuzování k nejlepšímu možnému vysvětlení tak podle konekcionismu neprobíhá na základě prohledávání nekonečného množství vysvětlení, ný-

\footnotetext{
${ }^{78}$ Churchland, Plato's Camera, 68-69.

${ }^{79}$ Ibid.

${ }^{80}$ Paul M. Churchland, „On the Nature of Explanation: A PDP Approach,“ in A Neurocomputational Perspective: The Nature of Mind and the Structure of Science (Cambridge, MA: MIT Press, 1992), 218.

${ }^{81}$ Churchland, Plato's Camera, 69-70.
} 
brž za pomoci zautomatizovaných procesů napříc neuronovou sítí vedoucí $\mathrm{k}$ aktivaci adekvátního vektoru. ${ }^{82}$ Tímto mechanismem pak konekcionismus vysvětluje, jak je možné, že jsme běžně schopni v konečném, a dokonce krátkém čase nalézt relativně adekvátní řešení daného problému.

\section{Sentenciální eliminativismus a lidová psychologie}

V úvodu článku jsem zavedl Clarkovo rozlišení na intenconiální a sentenciální eliminativismus. Intencionální eliminativismus odmítá možnost jakéhokoli popisu mentálních stavů odvolávajícího se na propoziční obsahy. Tato silnější pozice, pokud by se ukázala platnou, by pochopitelně vedla k eliminaci lidové psychologie, která takové popisy mentálních stavů poskytuje. Sentenciální eliminativismus na druhou stranu odmítá pouze tvrzení, že mentální reprezentace sdílejí stejnou skladebnou strukturu jako věty sloužící $\mathrm{k}$ jejich popisu. Mnohé argumenty proti lidové psychologii a konekcionistický přístup, ke kterému se Churchlandovi od devadesátých let přiklánějí, podporují tedy podle Clarka spíše slabší stanovisko sentenciálního eliminativismu. Toto tvrzení lze pak podpořit např́íklad i rozhovorem z roku 2015, v němž Patricia Churchlandová zdůrazňuje význam kritiky jazykového pojetí reprezentací v rámci eliminativního materialismu:

Paul poukázal na to, že [...] potřebujeme pojetí reprezentace, které je podobné přesvědčení, ale ne tolik svázané s jazykem. Jeho myšlenka byla, že co skutečně potřebujeme, je nahradit pojem přesvědčení velmi odlišným druhem reprezentace. Toto byl hlavní cíl eliminativního materialismu. ${ }^{83}$

Nicméně i navzdory této skutečnosti chápou Churchlandovi kritiku hypotézy jazyka myšlení jako zdrcující rovněž pro lidovou psychologii. Lidová psychologie pak zůstává předmětem kritiky i v jejich pozdějších textech, a to alespoň jako zdroj mylného sentencialistického pojetí mysli. ${ }^{84}$

Tento oddíl se tedy blíže zaměří na otázku, zda sentenciální eliminativismus implikuje eliminativismus intencionální. Tu lze pak zúžit na problém ontologických závazků lidové psychologie a otázku, nakolik je lidová psychologie svázána s předpokladem mentálního jazyka a lingvisticky strukturovaných mentálních reprezentací.

${ }^{82}$ Viz Churchland, „On the Nature of Theories,“ 218-23; Churchland, Plato’s Camera, 68-70.

${ }^{83}$ Bruno Mölder and Patricia S. Churchland, "Neuroscience Is Relevant for Philosophy,"

Problemos 88, no. 88 (2015): 176.

${ }^{84}$ Churchland, Plato's Camera, 5, 18. 
William Bechtel a Adele Abrahamsenová píší, že kritika lidové psychologie velmi často cílí spíše na filosofické konstrukty jiných filosofů než na psychologické perspektivy používané běžnými lidmi. ${ }^{85}$ Domnívám se, že toto tvrzení dobře vystihuje situaci eliminativního materialismu Churchlandových, kteři ve své kritice lidové psychologie cílí spíše na filosofický konstrukt Jerryho Fodora. Jak bylo ukázáno v druhém oddíle, jsou pro Fodora lidová psychologie a hypotéza jazyka myšlení úzce propojeny. Lidová psychologie poskytující každodenní psychologická vysvětlení za pomoci konceptů jako jsou přání a přesvědčení, je podle Fodora $\mathrm{z}$ podstatné části platná teorie, kterou je možné a žádoucí obhájit pomocí vědecké psychologie pracující s propozičními postoji. ${ }^{86}$ Toho pak chce docílit právě za pomoci předpokladu jazyka myšlení - „nekonečné sady ,mentálních reprezentací, které slouží jako př́mé předměty propozičních postojů i jako doména mentálních procesů. ${ }^{\text {"87 }}$ Domnívám se, že takovou charakteristiku lidové psychologie a snahu o její rozpracování na úrovni vědecké psychologie lze vnímat jako jednu z hlavních motivací kritiky lidové psychologie ze strany eliminativního materialismu.

Lze ovšem pochybovat, zda lidová psychologie skutečně předpokládá existenci jazyka myšlení. Podle některých filosofů by měly být každodenní lidové psychologii přisuzovány značně menší ontologické závazky, než jaké vyžaduje jazyk myšlení. ${ }^{88}$ Podle Andyho Clarka pak spojení lidové psychologie a jazyka myšlení vychází z "nebezpečného“ předpokladu, že lidová psychologie je teorií o hlubší povaze našich vnitřních reprezentací. ${ }^{89}$ Jak ovšem dodává, hlavním cílem lidové psychologie není charakterizovat

\footnotetext{
${ }^{85}$ William Bechtel and Adele A. Abrahamsen, „Connectionism and the Future of Folk Psychology," in Folk Psychology and the Philosophy of Mind, eds. Scott M. Christensen and Dale R. Turner (Hillsdale, NJ: L. Erlbaum, 1993), 344.

${ }^{86}$ Fodor, Psychosemantics.

${ }^{87}$ Ibid., 16-17.

${ }^{88}$ Rovněž tento článek vychází z předpokladu, že lidová psychologie představuje teorii poměrně slabými ontologickými závazky. Viz Clark, „Varieties of Eliminativism“; Andy Clark, „Dealing in Futures: Folk Psychology and the Role of Representations in Cognitive Science," in The Churchlands and Their Critics, ed. Robert N. McCauley (Blackwell, 1996); Bechtel and Abrahamsen, „Connectionism and the Future of Folk Psychology“; Terence Horgan and James Woodward, „Folk Psychology is Here to Stay,“ The Philosophical Review 94, no. 2 (1985): 197. Zároveň je ale nutné dodat, že ač je toto pojetí lidové psychologie blízké Dennettovu instrumentalismu, není s ním ztotožnitelné, protože se jedná o silnější pozici, která na rozdíl od instrumentalismu považuje entity lidové psychologie za kauzálně aktivní. Viz Daniel C. Dennett, „Tri druhy intencionálnej psychológie““in Mysel”, telo, stroj, eds. Egon Gál a Jozef Kelemen (Bratislava: Bradlo, 1992), 168-86.

${ }^{89}$ Clark, „Varieties of Eliminativism,“ 229.
} 
způsob kódování našich reprezentací, ale spíše jejich obsah. To, že tento obsah mentálních stavů lze popsat propozicemi, ještě nemusí znamenat, že samotné mentální stavy mají větnou strukturu. Na jiném místě předkládá Clark obdobný argument a píše, že na lidovou psychologii je vytvářen značný tlak snahou o to „identifikovat přání a přesvědčení (a vše ostatní) s vědecky

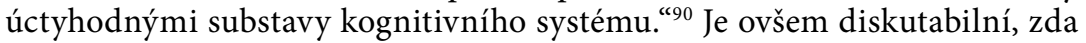
běžná lidová psychologie skutečně stanovuje či nutně předpokládá strukturu a hlubší charakter vnitřních stavů, které jsou popisovány propozičními postoji.

Společně s Clarkem se domnívám, že konceptuální rámec lidové psychologie v konečném důsledku předpokládá nanejvýše, že „existuje nějaký druh vnitřního stavu či stavů, které jsou kauzálně potentní a které nějakým způsobem zakládají specifické mentální obsahy, ke kterým se odkazujeme při lidově psychologickém popisu. " ${ }^{\text {"1 }}$ Nemyslím si, že bychom od lidové teorie, každodenně používané „běžnými“ lidmi pro vysvětlení motivací a chování druhých, měli očekávat snahu o jakkoli hlubší analýzu. Také Paul Churchland ostatně uznává, že termíny lidové psychologie jsou stejně jako termíny jakékoli jiné teorie definovány funkcionálně $s$ odkazem $\mathrm{k}$ jejich kauzálním rolím; tedy ve vztahu k smyslovým stimulům, behaviorálním výstupům a ostatním mentálním stavům. ${ }^{92}$ Takto definované entity mají pak poměrně malé závazky vůči svým zakládajícím fyzikálním stavủm, jež mohou být strukturovány odlišně od vět, které je popisují. Stejně tak mohou být tyto zakládající stavy silně distribuované a holistické, jako je tomu v případě neuronových sítí.

Tyto nízké závazky lidové psychologie lze ilustrovat rovněž tím, že i navzdory nesentenciálnímu distribuovanému kódování v neuronových sítích je stále možné je neproblematicky popisovat za pomoci propozičních postojů, jak ostatně velká část konekcionistikého výzkumu činí. ${ }^{93}$ Dokonce

\footnotetext{
${ }^{90}$ Clark, „Dealing in Futures,“ 91.

${ }^{91}$ Ibid., 89.

${ }^{92}$ Churchland, „Eliminative Materialism,“ 68-69. Tento pohled na lidovou psychologii je velmi blízký pozici Davida Lewise, na kterého se Churchland rovněž odkazuje. Viz David K. Lewis, „Psychophysical and Theoretical Identifications,“ Australasian Journal of Philosophy 50, no. 3 (1972): 249-58; Paul M. Churchland, „Folk Psychology,“ in On the Contrary: Critical Essays, 1987-1997, eds. Patricia S. Churchland and Paul M. Churchland (Cambridge, MA: MIT Press, 1999), 6-7.

${ }_{93}$ Tento postřeh lze nalézt hned v několika článcích. Viz Clark, „Varieties of Eliminativism“; Bechtel and Abrahamsen, „Connectionism and the Future of Folk Psychology“; Terence Horgan and John Tienson, "Connectionism and the Commitments of Folk Psychology," Philosophical Perspectives 9 (1995): 127-52.
} 
i Sítě A a B z článku Ramseyho a kol..$^{94}$ lze popsat jako reprezentující věty „psi mají srst“ apod. Skutečnost, že je tato propozice kódována nesentenciálně a silně distribuovaně nijak neznemožňuje lidově psychologický popis. Jak píší Terence Horgan a John Tienson, kdyby takový popis nebyl možný, jednalo by se o špatný konekcionistický model.${ }^{95}$ Reprezentace v konekcionistických sítích tak nemusí ani v nejmenším připomínat strukturu propozičních popisů. Tyto reprezentace mohou být silně distribuované např́íc sítí. Dokud však alespoň přibližně zastávají kauzální role, které plní entity lidové psychologie, lze je s nimi s určitou mírou přesnosti identifikovat. V tomto ohledu lze tedy říci, že i neuronové sítě určitým silně distribuovaným způsobem ukládají přání a přesvědčení a lze je popisovat za pomoci lidové psychologie.

Lidová psychologie s oslabenými ontologickými závazky tedy dle mého názoru není ve významné míře svázána s hypotézou jazyka myšlení a př́ípadná neexistence mentálního jazyka Fodorova typu se jí nemusí dotknout. Argumentace opírající se o konekcionistické modelování kognice, kterou od devadesátých let rozpracovávají Churchlandovi, tedy skutečně dokazuje pouze sentenciální eliminativismus, ale nikoli už intencionální. ${ }^{96}$

Než téma ontologických závazků opustím, musím zmínit ještě jeden aspekt lidové psychologie, který poukazuje na její relativní flexibilitu: nedomnívám se na rozdíl od Paula Churchlanda, že lze lidovou psychologii považovat za stagnující teorii neměnnou od dob Sofokla. ${ }^{97}$ Horgan a Woodwarad proti tomuto tvrzení uvádějí zajímavé příklady poukazující na vývoj každodenních psychologických vysvětlení v průběhu posledních dvou staletí. ${ }^{98}$ Zmiňují např́klad ve 20 . století rostoucí tendenci vysvětlo-

\footnotetext{
${ }^{94}$ Viz oddíl 3.1 tohoto článku.

${ }^{95}$ Horgan and Tienson, „Connectionism,“ 145.

${ }^{96}$ Nevylučuji, že je možné vytvořit jiný silnější argument, který by útočil přímo na platnost lidové psychologie a jejích kategorizací mentálních stavů. Mohlo by tomu být například $\mathrm{v}$ situaci, kdy bychom zjistili, že funkcionální entity lidové psychologie systematicky nekorelují s entitami teorií popisujících nižší úrovně organizace, které mají entity lidové psychologie zakládat. Cílem zde předloženého argumentu je ovšem pouze tvrzení, že argumentace proti hypotéze jazyka myšlení a jazykově pojímané kognici lidovou psychologii nevyvrací.

${ }^{97}$ Churchland, „Eliminative Materialism.“ Je diskutabilní, do jaké míry je tento argument aktuální. V pozdějších textech Patricie Churchlandové lze nalézt přiznání, že se lidová psychologie vyvíjí a je možné, že by se mohla vyvíjet v návaznosti na neurovědecký výzkum. Churchlandová nicméně stále zastává tvrzení, že změny, kterými by lidová psychologie musela projít, by byly tak radikální, že by byly až eliminativní. Churchland, Neurophilosophy; Churchland, Brain-Wise.

${ }^{98}$ Horgan and Woodward, „Folk Psychology is Here to Stay,“ 201.
} 
vat chování situačními faktory, nikoli charakterovými typy, které častěji figurovaly ve vysvětleních v 18. a 19. století. Dalším uváděným prríkladem je pak rovněž rostoucí ochota odkazovat se na vliv nevědomých přesvědčení a přání. Bechtel a Abrahamsenová pak připomínají ještě drastičtější změnu $\mathrm{v}$ historii lidové psychologie, a totiž, že zatímco dnes obecně lokalizujeme přesvědčení a přání do hlavy a mozku, byly $\mathrm{v}$ jiných historických obdobích spojovány spíše s oblastí srdce. ${ }^{99}$

Tyto př́íklady ještě lépe ilustrují relativně nízké ontologické závazky lidové psychologie a její výslednou vysokou flexibilitu. Lidová psychologie je schopna vývoje reflektujícího rostoucí vědecké poznání a zdá se, že jím v historii už nejednou prošla. Ukázalo-li by se, že kategorie lidové psychologie neodpovídají $\mathrm{v}$ dostatečné míre konekcionistickým modelům a neurovědě, nemusí tato skutečnost nutně vést $\mathrm{k}$ eliminaci lidové psychologie. Lidová psychologie nemusí v takové situaci projít radikální teoretickou změnou, jak předpokládá eliminativní materialismus, ale pouze konzervativní - upravit některé své entity, aby odpovídaly současnému poznání, tak, jak už se v dějinách stalo dř́ve. ${ }^{100}$

\section{Možnosti lidové psychologie}

Lidovou psychologii lze chápat jako poměrně flexibilní teorii s minimálními ontologickými závazky, která není v přímém ohrožení ze strany sentenciálního eliminativismu a konekcionismu. To s sebou ovšem přináší důležitou otázku, jakou roli může takto chápaná lidová psychologie hrát a jaké je její možné postavení ve vědeckém zkoumání mysli. Domnívám se, že lidová psychologie $\mathrm{v}$ podobě, $\mathrm{v}$ jaké byla výše hájena proti sentenciálnímu materialismu, by v tomto záměru neměla zastávat žádné výsadní postavení. Vracíme se tak opět $k$ původním cílům eliminativního materialismu Paula a Patricie Churchlandových, který rovněž usiloval o to, aby lidová psychologie nebyla vnímána jako nutně pravdivá, autonomní a neredukovatelná teorie, která může stanovovat explananda vědeckému zkoumání mysli. ${ }^{101}$ Neexistuje totiž důvod, proč by lidová psychologie coby ontologicky neukotvená a fle-

\footnotetext{
${ }_{99}$ Bechtel and Abrahamsen, „Connectionism and the Future of Folk Psychology,“ 356. Tato skutečnost pak ještě lépe dokládá nízké ontologické závazky lidové psychologie směrem k její fyzické realizaci. Měla-li by totiž být lidová psychologie eliminována, pak nejspíše právě v moment, kdy se ukázalo, že své entity nesprávně situovala do jiného orgánu.

${ }^{100}$ Viz Horgan and Tienson, „Connectionism,“ 139-40.

${ }^{101}$ Viz Churchland, „A Perspective on Mind-Brain Research“; Churchland, „Eliminative Materialism“; Churchland, Neurophilosophy.
} 
xibilní teorie měla ve zkoumání mysli zastávat privilegované postavení, jaké jí přisuzoval Fodor. Bylo by pak chybné považovat její konceptuální rámec, který se historicky proměňuje s dobovým poznáním mysli a těla (a často $\mathrm{v}$ návaznosti na něm), za zdroj platných a rigidních kategorií, které by měly být dále rozpracovány vědeckou psychologií a neurovědou.

Toto tvrzení nijak nezavazuje ke strategii budování vědecké teorie mysli čistě zdola (bottom-up). Sama Churchlandová obhajuje možnost koevoluce teorií na nižších a vyšších úrovních organizace, mezi které lidová psychologie nepochybně patří. ${ }^{102}$ Při tomto vzájemném kontaktu by ovšem mělo být $\mathrm{s}$ lidovou psychologií nakládáno jako se sice bohatou lidovou teorií, která však nemá za cíl popisovat hlubší charakter mentálních stavů a jejich substrátu, a tedy nemusí být pro tento cíl vhodná.

Zde předkládané stanovisko vůči lidové psychologii odporuje širšímu záměru intencionálního eliminativismu, je však plně kompatibilní s eliminativismem sentenciálním, který, jak jsem se snažil ukázat, hraje $\mathrm{v}$ argumentaci Churchlandových významnější roli. Navzdory tomu, že se toto stanovisko rozchází s eliminativismem Churchlandových v názoru na charakter lidové psychologie, se domnívám, že naplňuje skromnější cíl o její odstranění z vědeckého výzkumu mysli a mozku či alespoň umenšení jejího vlivu.

\section{Závěr}

Záměr tohoto článku byl dvojí: Za prvé představit argumentaci eliminativního materialismu proti hypotéze jazyka myšlenía jazykovému pojetíkognice jako významnější část eliminativismu Paula a Patricie Churchlandových. Za druhé to pak byla snaha o přehodnocení vztahu eliminativního materialismu a lidové psychologie. $V$ tomto ohledu se článek pokusil demonstrovat, že argumenty eliminativního materialismu vycházející z konekcionismu cílí primárně proti sentencialismu a nezakládají důvod pro eliminaci lidové psychologie. Lidová psychologie totiž pravděpodobně nepředpokládá existenci mentálního jazyka, a není tedy ohrožena argumentem sentenciálního eliminativismu. Motivací pro oba tyto cíle byla pak snaha o revidování obecně přijímaného pohledu na churchlandovský eliminativní materialismus, ale i na některá stanoviska Churchlandových samých, a ukázat tak moderní eliminativní materialismus jako udržitelnější a perspektivnější pozici, než jak bývá často vnímána.

${ }^{102}$ Churchland, Neurophilosophy, 362-86. 


\section{Bibliografie:}

Barlassina, Luca, and Robert M. Gordon. „Folk Psychology as Mental Simulation." In Stanford Encyclopedia of Philosophy. Stanford University, 1997-. Article published on March 28, 2017. https://plato.stanford.edu/entries/folkpsych-simulation/.

Bechtel, William, and Adele A. Abrahamsen. „Connectionism and the Future of Folk Psychology." In Folk Psychology and the Philosophy of Mind, edited by Scott M. Christensen and Dale R. Turner, 340-67. Hillsdale, NJ: L. Erlbaum, 1993.

Clark, Andy. „Dealing in Futures: Folk Psychology and the Role of Representations in Cognitive Science." In The Churchlands and Their Critics, edited by Robert N. McCauley, 86-103. Cambridge: Blackwell, 1996.

Clark, Andy. „The Varieties of Eliminativism: Sentential, Intentional and Catastrophic." Mind \& Language 8, no. 2 (1993): 223-33. https://doi.org/10.1111/j.1468-0017.1993.tb00282.x.

Cottrell, Garrison W. „Extracting Features From Faces Using Compression Networks: Face, Identity, Emotion, and Gender Recognition Using Holons.“ In Connectionist Models, edited by David S. Touretzky, Jeffrey L. Elman, Terrence J. Sejnowski, and Geoffrey E. Hinton, 328-37. San Francisco: Morgan Kaufmann, 1991. https://doi.org/10.1016/B978-1-4832-1448-1.50039-1.

Dennett, Daniel C. „Artificial Intelligence as Psychology and as Philosophy.“ In Brainstorms: Philosophic Essays on Mind and Psychology, 109-26. Montgomery, VT: Bradford Books, 1978.

Dennett, Daniel C. „Cognitive Wheels: The Frame Problem of AI.“ In Minds, Machines, and Evolution: Philosophical Studies, edited by Christopher Hookway, 129-52. Cambridge: Cambridge University Press, 1986.

Dennett, Daniel C. „Tri druhy intencionálnej psychológie.“ In Mysel, telo, stroj, editovali Egon Gál a Jozef Kelemen, přeložil Egon Gál, 168-86. Bratislava: Bradlo, 1992.

Fodor, Jerry A. Psychosemantics: The Problem of Meaning in the Philosophy of Mind. Cambridge, MA: MIT Press, 1987.

Fodor, Jerry A. The Language of Thought. New York: T. Y. Crowell, 1975. 
Fodor, Jerry A. The Mind Doesn't Work That Way: The Scope and Limits of Computational Psychology. Cambridge, MA: MIT Press, 2000. https://doi.org/10.7551/mitpress/4627.001.0001.

Fodor, Jerry A., and Zenon W. Pylyshyn. „Connectionism and Cognitive Architecture.“ Cognition 28, no. 1-2 (1988): 3-71.

https://doi.org/10.1016/0010-0277(88)90031-5.

Fodor, Jerry, and Brian P. McLaughlin. „Connectionism and the Problem of Systematicity: Why Smolensky's Solution Doesn't Work.“ Cognition 35, no. 2 (1990): 183-205. https://doi.org/10.1016/0010-0277(90)90014-B.

Garson, James. „Connectionism.“ In Stanford Encyclopedia of Philosophy. Stanford University, 1997-. Article published August 16, 2019. https://plato.stanford.edu/entries/connectionism/.

Horgan, Terence, and John Tienson. „Connectionism and the Commitments of Folk Psychology.“ Philosophical Perspectives 9 (1995): 127-52. https://doi.org/10.2307/2214215.

Horgan, Terence, and James Woodward. „Folk Psychology is Here to Stay.“ The Philosophical Review 94, no. 2 (1985): 197. https://doi.org/10.2307/2185428.

Hř́bek, Tomáš. Metafyzika antiindividualismu. Praha: Filosofia, 2008.

Hř́bek, Tomáš. „Na obranu lidové psychologie.“ Filosofický časopis 43, č. 5 (1995): 858-61.

Churchland, Patricia S. „A Perspective on Mind-Brain Research.“ The Journal of Philosophy 77, no. 4 (1980): 185-207. https://doi.org/10.2307/2025588.

Churchland, Patricia S. Brain-Wise: Studies in Neurophilosophy. Cambridge, MA: MIT Press, 2002.

Churchland, Patricia S. „Can Neurobiology Teach Us Anything about Consciousness?" Proceedings and Addresses of the American Philosophical Association 67, no. 4 (1994): 23-40. https://doi.org/10.2307/3130741.

Churchland, Patricia S. „Language, Thought, and Information Processing.“ Noûs 14, no. 2 (1980): 147-70. https://doi.org/10.2307/2214858.

Churchland, Patricia S. Neurophilosophy: Toward a Unified Science of the MindBrain. Cambridge, MA: A Bradford Book, 1989. https://doi.org/10.7551/mitpress/4952.001.0001. 
Churchland, Patricia S., and Terrence J. Sejnowski. „Neural Representation and Neural Computation." Philosophical Perspectives 4 (1990): 343-82. https://doi.org/10.2307/2214198.

Churchland, Patricia S., and Terrence J. Sejnowski. The Computational Brain. Cambridge, MA: MIT Press, 1996.

Churchland, Paul M. A Neurocomputational Perspective: The Nature of Mind and the Structure of Science. Cambridge, MA: MIT Press, 1992. https://doi.org/10.7551/mitpress/4940.001.0001.

Churchland, Paul M. „Connectionism as Psychology." In The Churchlands and Their Critics, edited by Robert N. McCauley, 232-38. Cambridge: Blackwell, 1996.

Churchland, Paul M. „Eliminative Materialism and the Propositional Attitudes.“ The Journal of Philosophy 78, no. 2 (1981): 67-90.

https://doi.org/10.5840/jphil198178268.

Churchland, Paul M. „Folk Psychology.“ In On the Contrary: Critical Essays, 1987-1997, edited by Patricia S. Churchland and Paul M. Churchland, 3-17. Cambridge, MA: MIT Press, 1999. https://doi.org/10.7551/mitpress/5123.001.0001.

Churchland, Paul M. „Functionalism at Forty: A Critical Retrospective.“ The Journal of Philosophy 102, no. 1 (2005): 33-50.

https://doi.org/10.5840/jphil2005102136.

Churchland, Paul M. Matter and Consciousness. Cambridge, MA: MIT Press, 2013.

Churchland, Paul M. „On the Nature of Explanation: A PDP Approach.“ In A Neurocomputational Perspective: The Nature of Mind and the Structure of Science, 197-230. Cambridge, MA: MIT Press, 1992.

Churchland, Paul M. „On the Nature of Theories: A Neurocomputational Perspective." In A Neurocomputational Perspective: The Nature of Mind and the Structure of Science, edited by Paul M. Churchland, 153-96. Cambridge, MA: MIT Press, 1992. https://doi.org/10.7551/mitpress/4940.001.0001.

Churchland, Paul M. Plato's Camera How the Physical Brain Captures a Landscape of Abstract Universals. Cambridge, MA: MIT Press, 2012.

https://doi.org/10.7551/mitpress/9116.001.0001. 
Churchland, Paul M. The Engine of Reason, the Seat of the Soul: A Philosophical Journey into the Brain. Cambridge, MA: MIT Press, 1996.

Churchland, Paul M. „The Evolving Fortunes of Eliminative Materialism.“

In Contemporary Debates in Philosophy of Mind, edited by Brian P. McLaughlin and Jonathan D. Cohen, 160-81. Malden, MA: Blackwell, 2007.

Lewis, David K. „Psychophysical and Theoretical Identifications.“ Australasian Journal of Philosophy 50, no. 3 (1972): 249-58.

https://doi.org/10.1080/00048407212341301.

Machery, Edouard. „You Don't Know How You Think: Introspection and Language of Thought." The British Journal for the Philosophy of Science 56, no. 3 (2005): 469-85. https://doi.org/10.1093/bjps/axi130.

Marvan, Tomáš, a Michal Polák. Vědomí a jeho teorie. Praha: Vyšehrad, 2015.

McCarthy, John, and Patrick J. Hayes. „Some Philosophical Problems from the Standpoint of Artificial Intelligence." In Machine Intelligence: No. 4, edited by Bernard N. Meltzer and Donald Michie, 463-504. Edinburgh: Edinburgh University Press, 1969.

Mölder, Bruno, and Patricia S. Churchland. „Neuroscience is Relevant for Philosophy.“ Problemos 88, no. 88 (2015): 176-86.

https://doi.org/10.15388/Problemos.2015.88.8487.

Ramsey, William. „How Not to Build a Hybrid: Simulation vs. Fact-Finding.“ Philosophical Psychology 23, no. 6 (2010): 775-95.

https://doi.org/10.1080/09515089.2010.529047.

Ramsey, William. „Systematicity and Architectural Pluralism. “ In The Architecture of Cognition: Rethinking Fodor and Pylyshyn's Systematicity Challenge, edited by Paco Calvo and John Symons, 253-73. Cambridge, MA: MIT Press, 2014. https://doi.org/10.7551/mitpress/9780262027236.003.0010.

Ramsey, William M., Stephen Stich, and Joseph Garon. „Connectionism, Eliminativism and the Future of Folk Psychology." Philosophical Perspectives 4 (1990): 499-533. https://doi.org/10.2307/2214202.

Rescorla, Michael. „The Computational Theory of Mind.“ In Stanford Encyclopedia of Philosophy. Stanford University, 1997-. Article published February 21, 2020. https://plato.stanford.edu/entries/computational-mind/. 
Rescorla, Michael. „The Language of Thought Hypothesis.“ In Stanford Encyclopedia of Philosophy. Stanford University, 1997-. Article published March 28, 2019. https://plato.stanford.edu/entries/language-thought/.

Rosenberg, Alexander. How History Gets Things Wrong: The Neuroscience of Our Addiction to Stories. Cambridge, MA: MIT Press, 2018.

https://doi.org/10.7551/mitpress/11905.001.0001.

Rumelhart, David E., James L. MacClelland, and PDP Research Group. Parallel Distributed Processing. Explorations in the Microstructure of Cognition: Volume 1: Foundations. Cambridge, MA: MIT Press, 1986. https://doi.org/10.7551/mitpress/5236.001.0001.

Sejnowski, Terrence J., and Charles R. Rosenberg. „Parallel Networks that Learn to Pronounce English Text." Complex Systems 1, no. 1 (1987): 145-68.

Shanahan, Murray. „The Frame Problem.“ In Stanford Encyclopedia of Philosophy. Stanford University, 1997-. Article published February 8, 2016. https://plato.stanford.edu/entries/frame-problem/.

Schneider, Susan. „The Language of Thought.“ In Routledge Companion to Philosophy of Psychology, edited by John Symons and Paco Calvo, 280-95. New York: Routledge, 2009.

Smolensky, Paul. „Connectionism, Constituency and the Language of Thought.“ In Meaning in Mind: Fodor and His Critics, edited by Barry M. Loewer and Georges Rey, 201-27.. Oxford: Blackwell, 1991.

Smolensky, Paul. „On the Proper Treatment of Connectionism.“ Behavioral and Brain Sciences 11, no. 1 (1988): 1-23. https://doi.org/10.1017/S0140525X00052432.

Smolensky, Paul. „Tensor Product Variable Binding and the Representation of Symbolic Structures in Connectionist Systems." Artificial Intelligence 46 (1990): 159-216. https://doi.org/10.1016/0004-3702(90)90007-M. 